\title{
Disaster Waste Management in Malaysia: Significant Issues, Policies \& Strategies
}

\author{
Nor Syazwani Yusof1, a, E.M.A Zawawi², and Zulhabri Ismail ${ }^{3}$ \\ ${ }^{2}$ Centre of Studies Construction Management, Faculty of Architecture, Planning and Surveying, 40450 UiTM Shah Alam, Selangor, Malaysia \\ ${ }^{1 \&}{ }^{3}$ Centre of Postgraduate Studies of Faculty of Architecture, Planning and Surveying, 40450 UiTM Shah Alam, Selangor, Malaysia
}

\begin{abstract}
Disaster Waste Management in Malaysia is still at the early stage of its research. Disaster can create large volumes of debris and waste and mismanagement of disaster waste can affect both the response and long term recovery of disaster affected area. The government of Malaysia is taking serious about this issue. This paper is aim to explore the issues, policies and strategies regarding disaster waste management in Malaysia. The objectives were to investigate the extent of disaster waste effects on the environment and to provide a basis from which the needs of waste management could be evaluated in disaster management guidelines. Qualitative method of data collection has been adopted in this study. The respondent are among the local authority and organization that involved in managing wastes. The finding shows that many of the policies regarding waste management in Malaysia has not been well implemented. The purpose of this paper is expected to improve the method of managing disaster waste in Malaysia.
\end{abstract}

\section{Introduction}

Human activity including construction works is causing climate change, which is becoming a major contributor to the increasing occurrence of natural disasters worldwide. Natural disasters happen every year and their impacts and frequency seem to have greatly increased in recent decades. For example, excessive rainfall in Malaysia has led to severe flooding in many parts of the country, particularly in agricultural areas largely as a result of deforestation and changes in agricultural practices. In order to improve the design strategy comprehensive flood warning systems, some research based on current risk management, flood mitigation and early warning systems has been implemented internationally. Every year, from day to day the volume of waste constantly increase and it is equivalent to waste production which were increased due to attitude of human. These degrees of waste management can affect long-term recovery in the affected areas. The economic effectiveness of a solid waste management system depends on life cycle costs for facilities and equipment and long-term effects of economic services provided [1]. Unfortunately, the practice of disaster waste management is often neglected or uncontrolled. This paper aimed to explore the issues, policies and strategies regarding disaster waste management practices to produce disaster management guidelines for Malaysia. Therefore, the main objectives of this paper were to investigate the extent of disaster waste effects on the environment and to provide a basis from which the needs of waste management could be evaluated in disaster management guidelines. The research output is expected to add to the existing body of knowledge on theoretical mechanisms for reducing adverse environmental impacts by way of policies and legal instruments, since there is still insufficient research in this area. The latest practices and strategies in disaster waste management will be prioritized in order to illustrate the magnitude of the existing problems encountered. A qualitative research design by way of case study, supported by quantitative research, will be adopted. The purpose of this paper is to explore the issues, policies and effects on our environment, social and economy in managing disaster in Malaysia.

\subsection{Weaknesses of disaster waste management in Malaysia}

A disaster waste management plan is essential to help a community identify options for collecting, recycling, and disposing of waste. Recycling and reusing disaster waste can replace natural raw materials and reduce the burden on the environment by reducing landfill. The aim is to develop an approach that looks at waste management policies as a way of identifying the possibilities and actions in order to manage waste wisely in the disaster management context. In Malaysia, the Inland Major Disaster Management Mechanism, under the National Security Council (NSC) of the Prime Minister's Department, was formed in May 1994 to coordinate all existing agencies in conducting relief activities during any major disaster on land. On 11 May 1997, the policy statement for disaster relief operations, entitled the

\footnotetext{
${ }^{\mathrm{a}}$ Corresponding author: emmamarinie@salam.uitm.edu.my
} 
National Security Council Directive 20 [2], was introduced. The main purpose of Directive 20 is to put in place a comprehensive emergency management programme which seeks to mitigate the effects of various hazards, to prepare for measures which will preserve life and minimize damage to the environment, to respond during emergencies and provide assistance, and to establish a recovery system to ensure the affected community's return to normalcy. The Mechanism coordinates and handles necessary actions to be taken in any major disasters by the existing rescue agencies, as well as the Special Malaysia Disaster Assistance and Rescue Team (SMART), so as to ensure that all actions can be immediately, efficiently and effectively carried out [3]. With natural disasters becoming more common, national waste management plans should be prepared to cope with this situation. Thus, the primary questions needing to be addressed are whether the current disaster management policies in Malaysia can effectively manage the disaster waste caused by flood in long-terms or shortterms planning.

On the threat of disaster waste to life and health could be overcome with an effective approach, which at the same time can recover and redevelop the damage facilities [4]. Unfortunately, current disaster waste management practice often involves either no action, in which the waste is left to accumulate and decompose, or inappropriate action, in which the waste is removed and dumped in an uncontrolled manner [5].Hence, this research aims to identify the gap in terms of existing policies and practices pertaining to disaster waste management. According to [6] implementation at the local level becomes one of the core factors in successful disaster waste management. A resilient disaster management system depends on the involvement and cooperation of all parties including the private sector, NGOs and the public. Cooperation between all agencies in carrying out their responsibilities is very important in determining the success and effectiveness of disaster management [7]. Thus, it is a necessary to consider waste management in disaster management guidelines Malaysia to curb this problem, otherwise the sustainability and environmental problems will not be addressed effectively. The current body of literature is also explored to identify the guidelines already formulated by the developed countries, from which we can learn, adopt and modify from more successful regimes.

\section{Research Aim, Objectives Research Questions}

and

The aim of this paper is to explore the issues, policies and strategies regarding disaster waste management in Malaysia. In order to achieve this aim, two (2) objectives are outlined:

1. To investigate the extent of disaster waste effects on the environment; (OBJ 1)

2. To provide a basis from which the needs of waste management could be evaluated in disaster management guidelines; (OBJ 2)

\subsection{Research questions}

In order to gauge the success of the research endeavour, the following research questions have been formulated:

\subsubsection{Research Questions for Objective 1}

$R Q$ 1.1: What are the main causes of disaster waste?

$\boldsymbol{R Q}$ 1.2: What is the extent of disaster waste effect on the environment?

\subsubsection{Research Questions for Objectives 2 and 3}

$\boldsymbol{R Q}$ 2.1: What issues and challenges are encountered during managing disaster waste?

$\boldsymbol{R} Q$ 2.2: What are the weaknesses of the current policies pertaining to waste management?

$\boldsymbol{R Q}$ 2.3: What could be formulated to improve disaster management guidelines pertaining to waste management?

\subsection{Previous studies related of research}

The studies shown in Table 1 that illustrate typical disaster waste management and its impact on the environment. Several studies showed the improvement of waste management and achieving a green environment are worldwide concerns.

\section{Research methodology}

Well planned research methodology is a guide to achieving the aim and objectives of research. Mixed methods of qualitative and quantitative research have been adopted in this study. A comprehensive literature review was conducted to gather information. Interview was conducted in October and November 2015. The responded were from local authorities and private sectors involved in managing disaster waste.

Table 2: Respondent's detail

\begin{tabular}{|c|c|c|}
\hline Respondents & Description/Position & $\begin{array}{c}\text { Number of } \\
\text { Respondent }\end{array}$ \\
\hline $\begin{array}{c}\text { Department of } \\
\text { Environment }\end{array}$ & Environmental Officer & 1 \\
\hline $\begin{array}{c}\text { Department of } \\
\text { National Solid } \\
\text { Waste }\end{array}$ & $\begin{array}{c}\text { Director of Technical } \\
\text { Department of National } \\
\text { Solid Waste } \\
\text { Management }\end{array}$ & 1 \\
\hline Alam Flora Sdn. & $\begin{array}{c}\text { Environmental } \\
\text { Officer/Supervisor } \\
\text { Landfill }\end{array}$ & 2 \\
\hline
\end{tabular}

Table 2 shows the respondent detail that involved in this research. The qualitative research design had been divided into three stages: qualitative instruments 
(interview and case study protocol and pilot exercise), semi-structured interview questions and the effects of

disaster previous to the case study.

Table 1. Previous studies on typical disaster waste management or issues and their impacts on the environment

\begin{tabular}{|c|c|c|c|c|}
\hline Year & Authors & Title of Research & Instruments & Remarks \\
\hline 2008 & [8] & $\begin{array}{l}\text { Estimation of waste } \\
\text { generation from floods }\end{array}$ & Case study & $\begin{array}{l}\text { The research focuses on the } \\
\text { flooded area and discusses the } \\
\text { parameters affecting floods waste } \\
\text { for the model development. }\end{array}$ \\
\hline 2010 & [9] & $\begin{array}{l}\text { Waste } r \text { management } \\
\text { strategies during post } \\
\text { disaster phase: A Case of } \\
\text { Sri Lanka }\end{array}$ & $\begin{array}{l}\text { Semi- } \\
\text { structured } \\
\text { interview }\end{array}$ & $\begin{array}{l}\text { This research focuses on the post- } \\
\text { disaster waste management } \\
\text { strategies adopted and on the } \\
\text { issues and challenges encountered } \\
\text { at both national and local levels in } \\
\text { Sri Lanka during the post - Indian } \\
\text { Ocean tsunami period. }\end{array}$ \\
\hline 2011 & [10] & $\begin{array}{l}\text { Environmental implications } \\
\text { for disaster preparedness: } \\
\text { Lessons Learnt from the } \\
\text { Indian Ocean Tsunami }\end{array}$ & Case study & $\begin{array}{l}\text { The research focuses on the } \\
\text { lessons learnt from the } \\
\text { environmental aspects of the } \\
\text { tsunami, strategies and its } \\
\text { implications for disaster } \\
\text { preparedness plans after disaster: } \\
\text { Indian Ocean Tsunami. }\end{array}$ \\
\hline 2011 & [11] & $\begin{array}{ll}\text { Disaster } & \text { waste } \\
\text { management: } & \\
\text { A systems approach } & \end{array}$ & $\begin{array}{ll} & \text { Case study } \\
\square & \text { Semi- } \\
& \text { structure } \\
& \mathrm{d} \\
& \text { interview }\end{array}$ & $\begin{array}{l}\text { This research focuses on } \\
\text { developing a systems } \\
\text { understanding of disaster of waste } \\
\text { management and in turn develops } \\
\text { context and disaster-transferrable } \\
\text { decision-making guidance for } \\
\text { emergency and waste managers. }\end{array}$ \\
\hline 2012 & [12] & $\begin{array}{l}\text { Disaster waste management } \\
\text { challenges }\end{array}$ & $\begin{array}{ll} & \begin{array}{l}\text { Survey } \\
\text { (questionn }\end{array} \\
\text { aire) } \\
\text { Semi- } \\
\text { structured } \\
\text { interview } \\
\text { Case study }\end{array}$ & $\begin{array}{l}\text { Discusses waste management } \\
\text { systems and challenges. }\end{array}$ \\
\hline 2013 & [13] & $\begin{array}{l}\text { Strategy for separation and } \\
\text { treatment of disaster waste: } \\
\text { A manual for earthquake } \\
\text { and tsunami disaster waste } \\
\text { management in Japan }\end{array}$ & D $\quad$ Case study & $\begin{array}{l}\text { This research focuses on existing } \\
\text { guidelines in waste management } \\
\text { in several of countries due to } \\
\text { disaster. }\end{array}$ \\
\hline 2014 & [14] & $\begin{array}{l}\text { Hazard and risk perception } \\
\text { at Turrialba volcano (Costa } \\
\text { Rica); } \\
\text { Implications for disaster } \\
\text { risk management }\end{array}$ & $\begin{array}{ll} & \begin{array}{l}\text { Semi- } \\
\text { structured }\end{array} \\
\text { interview } \\
\text { Case study }\end{array}$ & $\begin{array}{l}\text { Concerns the socio-economic } \\
\text { dimensions of hazards and how } \\
\text { these factors can be integrated } \\
\text { into disaster risk reduction at } \\
\text { Turrialba volcano (Costa Rica) }\end{array}$ \\
\hline 2014 & [15] & $\begin{array}{l}\text { Location and routing } \\
\text { problems of debris } \\
\text { collection operation } \\
\text { after disasters with realistic } \\
\text { case study }\end{array}$ & $\begin{array}{ll} & \text { Case study }\end{array}$ & $\begin{array}{l}\text { This research concerns the debris } \\
\text { collection operation hindered by } \\
\text { limited access, } \\
\text { Like blocked access by debris. }\end{array}$ \\
\hline
\end{tabular}

The interview and case study protocol and qualitative instrument will be prepared to ensure reliability and validity of the qualitative data then piloted with a targeted group prior to the actual data collection process; the purpose of this exercise is to maintain internal validity of the data and reliability of the instrument. Semi-structured interview questions will be selected to be put to professionals involved in disaster waste management. The selected samples of interviewee should consist of policy makers from government related agencies relevant to disaster waste management. The sampling frame of the target group will be identified before the actual data collection takes place. Due to the nature of qualitative research, the data will be collected until saturation point is achieved. Based on the case study, observation, parameters will be established to observe the current status of disaster waste management in Malaysia. The research will be focused on selected major post-disaster events such as floods in East Malaysia (Kuala Krai, Kelantan; Temerloh, Pahang). For each case study, qualitative data will be gathered from post-disaster literature (government reports, documents and legislation; 
practitioner, reports etc.).The third method of data collection wills, draft proposed waste management principles for adaption into disaster management guidelines. The last method is to ensure validity of the findings and the proposed guidelines. Data from the literature review, semi-structured interviews and document analysis will be juxtaposed and contextualised. This research is expected to emphasize the importance of the implementation of efficient disaster waste management in order to sustain ecological systems and enhance the social well-being of all Malaysian citizens and future generations. From the fundamental theoretical aspects, this research will proposed the adoption of disaster waste management into disaster management guidelines. It is expected to encourage further research and detailed investigation on disaster waste management and sustainable development. Future collaboration with relevant government will be appreciated. This paper only presents data from the interview sessions with the selected respondents.

\section{Results and discussion}

The researcher found that the authorities should play their role towards sustainable waste management after disasters such as floods. Four (4) respondents were selected, from the Department of Environment (DOE) in Putrajaya, Department of National Solid Waste in the Ministry of Urban Wellbeing, Housing and Local Government and from the private sector; Alam Flora Sdn. Bhd. The interview sessions were conducted in October 2015.The working experience of the selected respondents was 5 years and above in the waste management industry. Climatic changes have made garbage disposal dumps the only method for efficient garbage disposal in Malaysia. To achieve sustainable and effective waste management, development strategies must go beyond purely technical considerations to formulate specific objectives and implement appropriate measures with regard to political, environmental, social, financial, economic and technical aspects of disaster waste management. In addition, four (4) strategies for achieving good disaster waste management were identified:

\subsection{Proper arrangement of the material by recycling, recovery and disposal method}

Disasters such as floods can produce a large quantity of waste, which will endanger people, block access roads, block drainage channels, and conceal trapped people after the disaster. Respondent 4 also recommended promoting the use of plastic recycling identification codes and labels in order to sort and recycle plastic packaging more easily, for both municipalities and the private sector.Although this helps to separate the different types of waste to be recycled, reused or disposed of sorting the waste after a disaster, must consider the evironmental, political, institutional, social, financial, economic and technical aspects. If possible, sort the rubble as it is being removed, and store reusable materials separately from the rest of the waste. Another way to manage the waste is by promoting the use of products made from recycled materials and fuel made from disaster waste.

“...in our list of planning now, we're planning to promote recycling materials by the next generation; meaning more focus on children (primary and secondary school) and of course it is cheaper than branded things "(Respondent 4)

\subsection{Improve the education and awareness of producers, the public and people involved in the disaster waste system/sector}

People affected by major disasters are badly traumatized, but giving them a task to do helps them to recover. The Environment Agency leads the way in cooperation between all the parties participating in education within the waste sector such as private sector contractors and sub-contractors:; Alam Flora Sdn. Bhd, Southern Waste Management Sdn Bhd, E-Idaman Sdn Bhd, in managing the waste in our country, as stated by Respondent 2 . Strategies that can be considered include:

i. Promoting the advantages of recycling of waste and practicing the 3Rs (Reduce, Reuse, Recycle) programmes and make one day only for collecting the waste.

ii. Informing people of the waste management hierarchy: reduce,reuse,recycle,recovery and dispose.

iii. Promoting the use of less hazardous alternatives such as chemicals during the production of goods

iv. Encouraging companies and institution to set up a certified environmental managements systems and follow a national environmental policy.

v. Appointing a 'specialist officer of disaster waste management' exclusively for Malaysia.

“...even though we had to do a lot of campaigns, promote everything, everywhere,publish the article, a lot of brochures about how to manage the waste, and used 3R system (Reduce,Reuse, and Recycle), our people nevertheless pretend to know nothing about waste,it is seen to be less efficient or still lacking awareness and all this makes us more worried about our future generation. In this case, we should add some more strategies such as campaigns in the schools, colleges or other institutions." (Respondent 2)

\subsection{Control and decrease waste generation}

i. Promote the production of goods to minimize waste generation after disaster or as used by people.

ii. The Environment Agensy should set up a portal or web site to inform the public about the ways of to re-use and control the waste and prevent waste generation in households or after disasters. 
iii. The roles and resposibilities of those involved in disaster waste management system should be known such as the Environmental Department, Solid Waste and Public Cleansing Management Corporation (Act 672), local authorities and contractors/sub-contractorts and agents. They should know their purpose and main duties and responsibilities when disaster occurs. According to the Respondent 3, the roles and responsibilities of all the parties involved in a disaster area are very important because each has their 'own style' in planning to solve these issues in short-terms actions.

“...they have to understand their own roles and responsiilities, if not the coordination of the organizations will be disorganized in terms of the operations planning due to their attitude" (Respondent 3)

\subsection{Improve and follow the existing policies and legislation in the waste system/sector}

İn general, disaster waste managemet is arranged and handled by several government agencies, from federal to state to local authorities. Due to lack of human and financial resources to manage solid waste and public cleansing, an integrated system for waste management and an interim privatisation period would take too long and make it more difficult to secure loans; this is one of the reasons the federal sector took over all the waste management systems, with two departments in 2007; National Solid Waste Management Department and Solid Waste and Public Cleansing Management Corporation [16]. Therefore, several strategies need to be improved, likes revising the Waste Management Act of 2012 and their definitions of terms; or defining the responsiblilities of each sector and improving the databases regarding quantities and types of waste that is treated. The system should be enforced, a deterrent to parties that do not abide by laws. According to Respondent 2, the existing policies on solid waste management focus on the household, municipal and 'normal waste' produced by our community. Consequently, disaster waste is not included in Act 672. Respondent 1 and 2 also stated in reality, the existing policies it seem not to be implemented, as there is lack of enforcement.

“...of course every year,we're faced with a flood disaster related to existing policies of waste management; Act 672 in Malaysia is for domestic waste and scheduled waste only and there is no enforcement of this act...to date, we do not use any policies, acts or guidelines on disaster waste management" (Respondent 2)

“...in the EIA report there is nothing related to disaster waste, but in my opinion other parties involved in waste management after the recent floods must have planning, playing their role and improving the existing policies related to disaster waste management, not just focusing on daily operation only " (Respondent 1)

This study identified several authorities and law under their jurisdiction in handling solid waste areas as shown in Table 2:

Table 3. Authorities involve in Disaster Waste Management

\begin{tabular}{|c|c|c|}
\hline Authorities & $\begin{array}{c}\text { Laws/Acts/ } \\
\text { Standard Policy }\end{array}$ & Scope/Remarks \\
\hline $\begin{array}{l}\text { National } \\
\text { Security } \\
\text { Division } \\
\text { (Prime } \\
\text { Minister's } \\
\text { Department) }\end{array}$ & $\begin{array}{l}\text { National Security } \\
\text { Council } \\
\text { Directive No. } 20 \\
\text { (The Policy And } \\
\text { Mechanism On } \\
\text { National Disaster } \\
\text { And Relief } \\
\text { Management) }\end{array}$ & $\begin{array}{l}\text { Outlines a Policy on } \\
\text { Disaster Management } \\
\text { and Relief according to } \\
\text { the level of disaster. The } \\
\text { purpose is determining } \\
\text { the roles and } \\
\text { responsibilities of the } \\
\text { various agencies } \\
\text { involved in handling } \\
\text { disaster. }\end{array}$ \\
\hline $\begin{array}{l}\text { Ministry of } \\
\text { Urban } \\
\text { Welbeing, } \\
\text { Housing and } \\
\text { Local } \\
\text { Government } \\
\text { of Malaysia }\end{array}$ & $\begin{array}{l}\text { Solid Waste and } \\
\text { Public Cleansing } \\
\text { Management Act } \\
2007 \text { (Act 672) }\end{array}$ & $\begin{array}{l}\text { This act as guidelines for } \\
\text { the management and } \\
\text { regulation of controlled } \\
\text { solid waste and public } \\
\text { cleansing for the purpose } \\
\text { of maintaining proper } \\
\text { sanitation. Normally, the } \\
\text { act is focuses on } \\
\text { household, municipal } \\
\text { and hazardous industrial } \\
\text { waste/areas. }\end{array}$ \\
\hline $\begin{array}{l}\text { Ministry of } \\
\text { Natural } \\
\text { Resources } \\
\text { and } \\
\text { Environment }\end{array}$ & $\begin{array}{l}\text { Environmental } \\
\text { Quality Act } 1974 \\
\text { (Act 127) } \\
\text {-Part IV Section } \\
24 \text { (2b) }\end{array}$ & $\begin{array}{l}\text { The EQA was enacted in } \\
1974 \text { and applies to the } \\
\text { whole of Malaysia. It is } \\
\text { related to the prevention, } \\
\text { abatement, control of } \\
\text { pollution } \\
\text { enhancement of the } \\
\text { environment, and for } \\
\text { purpose connected } \\
\text { therewith. }\end{array}$ \\
\hline $\begin{array}{l}\text { Department } \\
\text { of Standards } \\
\text { Malaysia/ } \\
\text { SIRIM } \\
\text { BERHAD }\end{array}$ & $\begin{array}{l}\text { Malaysian } \\
\text { Standard Landfill } \\
\text { Safe Closure- } \\
\text { Requirements } \\
\text { (MS 2547:2014) }\end{array}$ & $\begin{array}{l}\text { This Malaysian Standard } \\
\text { specifies requirements } \\
\text { for landfill safe closure } \\
\text { and it is to protect public } \\
\text { health and the } \\
\text { environment by proper } \\
\text { management of such. }\end{array}$ \\
\hline
\end{tabular}

Sources: National Security Council Directive No.20 [3], ACT 672 [18], ACT 127 [19] and MS 2547:2014 by SIRIM [20].

Table 3. above shows the first authority is an organization under the National Security Council (NSC) of the Prime Minister's Department Malaysia, which introduced Directive No. 20 (Policy and Mechanism on National Disaster and Relief Management). The scope of this directive is according to the level of disaster:, Level 1:District; Level II: State; Level III: Central [3]. The main purpose of this policy is to form a team and coordinate agencies involved in disaster management [17] and to determine the roles and responsibilities of the agencies involved in handling the disaster. The second authority is the Ministry of Urban Wellbeing, Housing and Local Government of Malaysia with its Solid Waste 
and Public Cleansing Management Act 2007 (Act 672); this act is normally implemented in daily events of waste management in Malaysia. It provides and regulates the management of controlled solid waste and public cleansing for the purpose of maintaining proper sanitation under the housing and local government authority. The regulation focuses on avoiding waste from contributing to improper sanitation. Even though the act did not specify disaster solid waste but it should be seen as part of controlled solid waste. However, the whole scope of managing the waste is not enough, as compared to the steps given in the waste management hierarchy. The next authority is the Ministry of Natural Resources and Environment with its Environmental Quality Act 1974 (Act 127). The act's scopes is to prevent, reduce, control pollution and to enhance the environment. Wastes in this act is more related to general environmental problems, such as sludge, odour and others. The waste is also interpreted as liquid, solid, gas and radioactive. The wastes is either normal waste or scheduled waste [21]. The drawback of this law is that it considers waste when it is deposited and causes pollution of the environment; it is not much involved after disasters, due to there being separate emergency methods. The final authority that concern waste is the Industry Standards Committee on Environmental Management (Department of Standards appointed SIRIM BERHAD as the agent to develop Malaysian Standards) which publishes new standards of requirements for landfill; Malaysian Standard Landfill Safe Closure- Requirements (MS 2547:2014). The landfill when completed must be closed properly for safe storage of the waste and prevention of pollution to the surrounding environment. Several requirements must be met to ensure that agencies using it as a guide meet landfill site requirements according to the Malaysian Standard.

In order for Malaysia to move towards a green or sustainable environment, the country has to benchmark developed nation like Japan in handling disaster waste issues. A diagram of disaster waste management strategies containing all the relevant variables is shown in Figure 1.

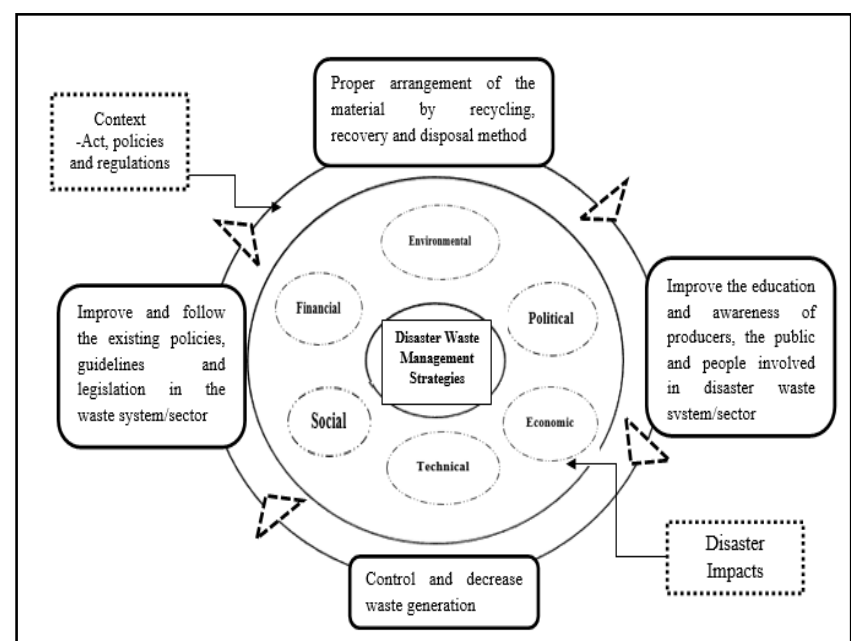

Figure 1. Cross-case study anaysis strategies of disaster waste management

\section{Scope and limitation}

This research focuses on the current situation and practices or initiatives of the disaster waste management in our country. Several authors have given their opinions and produced their definitions of waste management, resulting in the existing policies and guidelines. The current problem is that implementing these policies and guidelines is not practicable as identified in Malaysia. In addition, the existing initiatives and policies, public and private, concerning waste management in Malaysia have been investigated to identify gaps in management planning and ways to control the waste following disasters. Therefore, strategies will be considered to achieve the aim and objectives of the research. Since the research involves various authorities in the waste management industry, the main target group includes the Solid Waste and Public Cleansing Management Corporation, and local authorities in Kelantan (Kuala Krai) and Pahang (Temerloh), which are important agencies pertaining to adapt disaster waste management guidelines in Malaysia and identifying full detailed problems. The limitation of this study is thus the small number of entities or individuals that play a significant role in waste management in Malaysia.

\section{Significant of research}

This research will add in to the existing body of knowledge on disaster waste management issues and policies since there are limited resources on this area of study. It is sponsored by the MOHE (Ministry of Higher Education) under the Fundamental Research Grant Scheme (FRGS) known as the Flood Disaster Management Grant. This research will not only benefit to government, but also other authorities involved in disaster waste management. The limited number of up to date primary sources is one of the main concerns in preparing this research and there is a gap in terms of what has been planned and actions that have been implemented in particular disaster waste management occurrences.

\section{Conclusions}

The disaster waste management strategies is useful approach to guide Malaysia for present and in the future. The findings are expected to be the cornerstone for disaster waste management in Malaysia. There is a gap in terms of what has been planned and the actions actually taken in particular disaster waste management events. Generally, disaster waste management issues in Malaysia have not been seriously addressed, thus more empirical evidence and research is required to provide information on the current scenario and the actions that should be taken. This study revealed that they are four (4) elements to be considered in this research which are based on social impact, economic impact, environmental impact and technical impact (i.e.: insufficient equipment, 
transportation problems etc.). In order to have a better disaster waste management in Malaysia, the factor could be highlighted for further study. These need more investigation from the researcher to look into the suitability of the factors to be adopted in the disaster management guideline in Malaysia. Developing a management strategy for Malaysia is the fundamental task of an agency's leader. Strategy indicates both where the agency wants to go (long-term objectives) and how it plans to get there (on its planning on waste management). The agency management strategy must be realistic in taking account both of limits and resources. That is, the strategy must be guided by the underlying reality of the setting in which objectives are pursued. In what follows, we use management strategy and implementation strategy as generally interchangeable. Furthermore, through the exploratory interview, it provides clarify on actual events on disaster waste management in Malaysia. Thus, the additional knowledge about strategies on disaster waste management in this paper will benefit all the parties involved in waste management. From the above, it can be anticipated that this research will generate interests from disaster waste researchers and disaster waste management policy makers, as it will provide fundamental elements towards a more rigorous disaster waste management policy.

\section{Acknowledgement}

The authors would like to express their gratitude for the financial support from MOHE (Ministry of Higher Education) under the Fundamental Research Grant Scheme (FRGS), 600-RMI/FRGS DIS 5/3 (7/2015) and also LESTARI GRANT (600-RMI/DANA 5/3/LESTARI (17/2015) which is internal grant of Universiti Teknologi MARA (UiTM) for the management and support of this research.

\section{References}

1. P. Schübeler, J. Christen, and C.- Berne, "UNDP / UNCHS (Habitat)/ World Bank / SDC Collaborative Programme on Municipal Solid Waste management in Low-Income Countries URBAN MANAGEMENT AND INFRASTRUCTURE Conceptual Framework for Municipal Solid Waste Management in LowIncome Countries," (1996).

2. C. O. Ver and S. T. O. Ry, "Disaster Management in Malaysia: Evolution, Development and Future Challenges," no. February, (2007).

3. National Security Council, "Disaster Management in Malaysia: Landscape Review, Challenges and Prospects," (2011).

4. G. Approach, "Cabarrus County, North Carolina," no. April, (2012).

5. MSPs, "Draft National Policy for Disaster Management in Kenya," no. February, pp. 1-50, (2009).
6. Did, "Government Of Malaysia Department Of Irrigation Volume 1 - Flood Management," vol. 1, (2009).

7. Hon Anna Bligh MP, "Disaster Management Strategic Policy Framework," State Disaster Management. Gr., no. 1, pp. 1-20, (2010).

8. H. Srinivas and Y. Nakagawa, "Environmental implications for disaster preparedness: Lessons Learnt from the Indian Ocean Tsunami, ”J. Environ. Manage, vol. 89, no. 1, pp. 4-13, (2008).

9. G. Karunasena, R. Amaratunga, and R. Haigh, "Waste management strategies during post disaster phase: A case of Sri Lanka," (2010).

10. M. Milke, "Disaster waste management research needs," Waste Management, vol. 31, no. 1, p. 1, (2011).

11. C. Brown, M. Milke, and E. Seville, "Disaster waste management: A review article," Waste Management, vol. 31, no. 6, pp. 1085-1098, (2011).

12. Periathamby, a., Hamid, F. S. \& Sakai, S. -i. Disaster waste management challenges. Waste Manag. Res. 30, 113-114 (2012).

13. M. Asari, S. I. Sakai, T. Yoshioka, Y. Tojo, T. Tasaki, H. Takigami, and K. Watanabe, "Strategy for separation and treatment of disaster waste: A manual for earthquake and tsunami disaster waste management in Japan," J. Mater. Cycles Waste Management, vol. 15, no. 3, pp. 290-299, (2013).

14. S. M. van Manen, "Hazard and risk perception at Turrialba volcano (Costa Rica); implications for disaster risk management," Appl. Geogr., vol. 50, pp. 63-73, (2014).

15. A. Pramudita, E. Taniguchi, and A. Qureshi, "Location and Routing Problems of Debris Collection Operation after Disasters with Realistic Case Study," Procedia - Soc. Behav. Sci., vol. 125, pp. 1-15, (2014).

16. T. J. Sin, G. K. Chen, K. S. Long, I. Goh, and H. Hwang, "Current practice of waste management system in Malaysia: Towards sustainable waste management Current Practices for Malaysia", in $1^{\text {st }}$ FPTP Postgraduate Seminar Towards sustainable waste management. (2013).

17. B. A. Rahman, "Issues of Disaster Management Preparedness: A Case Study of Directive 20 of National Security Council Malaysia," Int. J. Bus. Soc. Sci., vol. 3, no. 5, (2012).

18. Ministry of Housing and Local Government, "Act 672, Solid Waste and Public Cleansing Management Act”, pp. 1-7, (2007).

19. Ministry of Natural Resources and Environment, "Act 127, Environmental Quality Act”, pp 1-17, (1974).

20. SIRIM, "MS 2547:2014- Malaysian Standard Landfill Safe Closure-Requirements," Sirim Berhad, Malaysia, (2014).

21. Mustafa, M, ".Environmental law in Malaysia. Kluwer Law International BV, the Natherlands”, pp. 98-99, (2011). 